\title{
THE ENFORCEMENT OF AMERICAN JUDGMENTS ABROAD
}

\author{
ERNEST G. LoRENZEN \\ Professor of Law, Yale University
}

As one studies the rules of the conflict of laws of the different countries, one is struck by the fact that most countries assume a fundamentally different attitude in the enforcement of foreign judgments from what they do with respect to foreign laws in general. ${ }^{1}$ Although there are various theories concerning the ultimate legal basis upon which the recognition and enforcement of foreign laws rest, there is agreement on the point that under modern conditions a state is in duty bound to determine the consequences of legal acts, under certain circumstances, in accordance with the law of some foreign state. Notwithstanding many differences in detail there exists to-day a striking similarity in the rules governing the conflict of laws in the various countries. An examination of the law governing the recognition and enforcement of foreign judgments in the different countries reveals, however, the surprising fact that there are, so far as this subject is concerned, no principles which have so far met with anything like universal approval.

This- difference in the enforcement of foreign laws and foreign judgments arises from a deep-rooted distrust in the administration of justice in other countries, and the fear arising therefrom that irreparable injury may be done to an individual. ${ }^{2}$ The laws of foreign countries apply, with few exceptions, with equal force to citizens and foreigners alike. In the case of foreign judgments it is felt, on the other hand, that the courts of certain countries, because of the incompetency, the lack of independence and partiality of their judges, do not afford sufficient guarantees of an even-handed and enlightened administration of justice. In many countries the view prevails that

\footnotetext{
${ }^{1}$ According to the earlier writers foreign judgments could be executed without the necessity of a new action or proceeding. Their attitude was based upon the theory that the Roman law governed all civilized countries which imposed a natural duty to recognize and enforce such judgments. Baldus, In primum, secundum et tertium codicis librum commentaria, Bk. I, tit. "de sum. Trinitate," n. 93. D'Argentré, Commentarii in patrias britonum leges, art. 218, glosse 6, n. 47. 3 Rolin, Principes de droit international privé, 45. The Dutch writers based the enforcement of foreign judgments on the doctrine of comity. J. Voet, " $A d$ pandectas," BK. 42, tit. I, 11. 4I. The modern rule arose only with the development of the doctrine of the independence of the different states.

${ }^{2} \mathrm{x}$ Hellwig, Lehrbuch des deutschen Civilprozesses, 123.
} 
the enforcement and recognition of foreign judgments can be established only through international conventions between countries that have confidence in each other's courts. ${ }^{3}$ Thus far very little has been accomplished, however, by this means. ${ }^{4}$ Through the initiative of the Dutch government in 1874 and of the Italian government in $188 \mathrm{I}$, efforts were made to have the subject matter under discussion regulated by an international convention, but these steps led to no practical results. Even at the time of the holding of the conferences of the Hague in I893, I894, I900 and 1904, which dealt with various topics in the conflict of laws, the time was not deemed ripe for an international agreement with respect to the enforcement of foreign judgments. The only international regulation on the general subject ${ }^{5}$ relates to the enforcement of coits, which is found in Article I6 of the International Convention on $C_{2} \cdot r i l$ Procedure, signed at the Hague on November 14, I8g6, and moriii :d by the Convention of July I7, I905. ${ }^{\circ}$

Greater progress in this directirn has been made by some of the South American countries, whic's at the Congress of Montevideo, in I889, agreed upon the conditions under which the judgments of the states ratifying the convention, should be enforced.?

Much dispute exists in the different countries concerning the question whether the principles governing the enforcement of foreign judgments should be applied also when foreign judgments are set up by way of defence to a new action. In support of a radical distinction between the principles applicable to the enforcement of foreign judgments and their recognition in res judicata, it is contended that the

\footnotetext{
- Bernard, De la compétence des tribunaux à l'égard des étrangers et de l'exécution des jugements étrangers en France. Etude de la convention francobelge du 8 juillet 1899; Fusinato, L'esecuzione delle sentenze straniere, 65; I Zitelmann, Internationales Privatrecht, 15.

'Schücking, The International Union of the Hague Conference (transl. by Fenwick), 149, 169, 174, 188. Klein, 24 Zeitschrift fïr internationales Privatund Strafrecht, II7. Haeger, Die Vollstreckung von Urteilen und Schiedsprïchen im internationalen Rechtsverkehr, 280. Schücking and Klein regard an international convention and an international court as the only possible solution of the problem. For the history of these efforts consult La Loggia, La esecuzione delle sentenze straniere, 49.

- See also art. 56 of the Convention on transportation by rail of October I4, I890.

' (I905) Revue de droit international privé, 782.

"Art. 5 of the Tratado de derecho procesal lays down the following conditions: (I) The foreign court must have had jurisdiction in the international sense; (2) the judgment must be subject to execution or res judicata where rendered; (3) the defendant must have been legally cited, represented or defaulted according to the law of the foreign state; (4) the enforcement of the judgment must not be opposed to the public policy of the state where such enforcement is sought. Ramirez, El derecho procesal internacional en el congreso juridico de Montevideo, III-Ir2.
} 
execution of judgments involves a direct act of sovereignty which should be allowed only after an examination of the fairness and justice of the foreign decision by the courts of the state in which execution is sought. With respect to the recognition of foreign judgments as res judicata it is maintained, however, by some writers, following in the footsteps of Roman 1 aw, ${ }^{8}$ that a judgment is in the nature of a contract or quasi-contract and that the obligation arising therefrom must, or should, be recognized upon the same footing as any other obligation when the judgment is pleaded in bar to another suit upon the same cause of action. ${ }^{\circ}$ By submitting the case to the foreign court the parties are deemed, according to this view, to have made an implied agreement that they will abide by the decision of the court. The obligation arising from the judgment is referred therefore to the will of the parties rather than being derived directly from the sovereign power of the foreign state. ${ }^{10}$ Others deny the contract or quasicontract theory, but support a similar distinction between the enforcement of foreign judgments and their recognition as res judicata on some general theory concerning the conflict of laws. ${ }^{11}$

Whatever basis there may have been in Roman law for the contract or quasi-contract theory of judgments, there can be no doubt that such a theory would rest to-day upon pure fiction, from which no solid conclusion can of course be drawn in the conflict of laws. Some of the

${ }^{8}$ According to the old Roman law the parties had to agree formally that they would recognize the judgment. A judicial proceeding came to be regarded, therefore, as possessing the nature of a contract. Even in later Roman law this notion was retained. See Girard, Manuel élémentaire de droit romain, (5th ed.) I008.

'Daguin, De l'autorité et de l'exécution des jugements étrangers, 40; Surville \& Arthuys, Cours élémentaire de droit international privé (6th ed.) 614; Thevenet, De l'autorité et de la force exécutoire des jugements étrangers en France et des jugements français dans les principaux états étrangers, 14-15. Contra, Fusinato, op. cit., 60; I Hellwig, Lehrbuch des deutschen Civilprozesses, I2I ; Moreau, Effets internationaux des jugements en matière civile. According to Lainé, Massé was the first to introduce this doctrine into France. (Ig02) Revue critique de législation, etc., 6Ig. So far as the defendant is concerned he has no option in the matter. The plaintiff also may under the circumstances of the case have had no choice regarding the place where the suit was to be brought.

${ }^{10}$ Valery calls attention to the fact that judgments by default show conclusively that the quasi-contract theory is a pure fiction and that the authority of the foreign judgment as res judicata rests solely on the will of the state. Manuel de droit international privé, 779.

${ }^{11}$ Von Bar was the first to develop the theory that a judgment is in the nature of a lex specialis. Private International Law (Gillespie's translation) sec. 412. See also, 3 Rolin, op. cit., 45. Despagnet and DeBoeck hold that the recognition of foreign judgments as res judicata without an exequatur follows from the respect due to the foreign judgment in its juridical existence. Manuel élémentaire de droit international privé (6th ed.) 6II. 
most distinguished recent writers ${ }^{12}$ have recognized this fact and hold therefore that the same principles should control the enforcement of foreign judgments as govern their recognition as res judicata. These writers have not always appreciated the fact, however, that both the enforcement of foreign judgments and their effect as res judicata depend to-day solely upon the sense of propriety and justice entertained by the legislator or courts of the state in which the question arises, and that the existence or non-existence of all rights depends in the last analysis upon the same law. ${ }^{13}$

Foreign judgments may relate to a great variety of subjects. The judgment in question may be-to give only a few illustrations-a divorce decree, a judgment determining the capacity of a party to enter into a contract, a bankruptcy decree, a decision of a prize court, or a judgment for the payment of money. With respect to many of these subjects there are great differences of policy; with respect to others the internal law of the various countries is more nearly alike, the similarity being closest in the law of obligations. ${ }^{14}$

\footnotetext{
${ }^{12}$ Audinet, Principes élémentaires de droit international privé (2d ed.) 382383; Haeger, op. cit., 236; Fusinato, op. cit., 60; Lainé (I902) Revue Critique, 98; Hellwig, Lehrbuch, 124; Moreau, op. cit., 621 ; Ramirez, op. cit., I13, I20; Restrepo-Hernandez, Derecho international privado, 572. Under section 723 of the German Code of Civil Procedure, there is little room for doubt. Francke, Anerkennung ausländischer Urteile nach Neujahr (1900), Zeitschrift für deutschen Civilprozoss (I900) I32; I Gaupp-Stein, Zivilprozessordnung für das deutsche Reich (Ioth ed.) 838; Kohler, Gesammelte Aufsätze, 562-563.

${ }^{13}$ As regards judgments for the payment of money it is held quite generally that they will be recognized as res judicata only after an exequatur has been obtained. France: Perroud, Clunet (I912) 847, note; Germany: sections 723 and 328 , Code of Civil Procedure; Hungary: Gottl, Ungarische Zivilprozessordnung, 307.

There is a great deal of authority, however, to the effect that a judgment regarding capacity and status, so far as it will be recognized at all, will have the effect of res judicata without an excquatur. App. Paris, July 6, I892, Clunet (1892) 1022; App. Paris, Apr. 6, 1903, Dalloz, 1904, 2, 273; Cass. Nov. II, 1908, Clunet (1909) 753; Swiss Federal Trib. July 12, I900, Clunet (1905) 746; Ottolenghi, De l'effet en Italie des jugements étrangers en matic̀re d'état et de capacité. Clunet ( 1902$) 760$.

Although the recognition of the foreign judgment as res judicata may be denied it may be possible to use the judgment as proof of the original cause of action. French Cass. Jan. 30, 1912, Clunet (1912) 845; Cass. Turin, July 21, I9r3, Clunet (1914) I36r.

"Because of the practical difficulties in the way of reaching an agreement regarding foreign judgments of certain kinds the Institute of International Law and the International Law Association have restricted their recommendations regarding the enforcement of foreign judgments to judgments for the payment of money. The Institute has recommended the following conditions as the basis of diplomatic conventions: (I) the establishment of uniform rules governing the jurisdiction of courts and a minimum of guarantees relative to procedure, such as citation and the time for appearance; (2) that there shall be no revision of the merits (révision au fond); (3) that foreign julgments
} 
The present article will attempt to point out to what extent American judgments for the payment of money are enforced in other countries. Their recognition abroad as res judicata is not within its scope.

From the standpoint of the mode of enforcing American judgments abroad the following systems may be distinguished.

I. Anglo-American system. According to English law a foreign judgment is never enforced as such. Execution will issue only on a domestic judgment. A foreign judgment for the payment of money is accepted, however, as evidence of the creation of an obligation which can be enforced by means of a new suit on the judgment. A similar system appears to prevail in Denmark. ${ }^{15}$ The proceedings in England are of a summary character and a new judgment may be obtained within ten days or two weeks.

2. Continental system. In most of the continental and South American countries execution will issue on the foreign judgment as such, but only after leave to do so has been obtained from the local government. ${ }^{16}$ In some of the Swiss cantons the preliminary or exequatur proceeding is a governmental or administrative one, ${ }^{17}$ but in most countries it has a judical character. In some countries, for example Germany, a formal action is necessary which the defendant may drag out for months by the interposition of all kinds of defences. Before the judgment of execution can be granted, a local creditor may have attached the property of the defendant, or the defendant himself may have secreted the property. ${ }^{18}$ A better system prevails in other countries, in Austria for example, where the foreign judgment is

shall not be enforced if they contemplate an act contrary to the public order or to prohibitory law of the state in which such enforcement is sought. 3 Annuaire de l'Institut de Droit International, 96-98.

The subject of the enforcement of foreign judgments is being studied again at the present time by the Institute of International Law. See Pillet's report, Annuaire (1913) 413, 432-433, and the observations thereon by Professors Sacerdoti and Rolin, Revue de droit international privé (1914) 210.

The Association for the Reform and Codification of the Law of Nations (now called The International Law Association) recommended the formation of international conventions on the following conditions: ( $I$ ) that the judgment was rendered by a court of competent jurisdiction, the rules of jurisdiction to be specified in the convention; (2) that the parties were duly cited; (3) if the judgment is by default that the defendant had notice of the suit and an opportunity to defend; (4) that the judgment contain nothing contrary to morality nor to the public policy or law of the state where it is to be enforced; (5) that it is subject to execution in the state where it was rendered; (6) that there shall be no review of the merits (révision au fond), but merely an examination of the legal conditions above mentioned. See Clunet (1883) 564 .

${ }^{15}$ Goos, De l'exécution des jugements en Denmark, Clunet (1880) 368.

${ }^{16}$ Haeger, op. cit., 236.

${ }^{17}$ See Roguin, De l'exécution des jugements en Suisse, to Clunet, 125.

${ }^{18}$ Sperl, Ein Staatsvertrag ïber die Vollstreckungshilfe zwischen Osterreich und Deutschland, 20 Zeitschrift für Internationales Privat- und Strafrecht, 57 ; Haeger, op. cit., 25. 
declared subject to execution upon the plaintiff's petition, after an examination by the court of the question whether the foreign judgment satisfies the requirements of the Austrian law for the enforcement of foreign judgments. The defendant is not informed of the proceeding until after the exequatur is granted and the judgment has become a lien upon his property. If he has any defences he is allowed to interpose them before execution is issued. ${ }^{10}$ The proceeding is swift in its operation and entails little expense.

Regarding the question whether foreign judgments will be enforced there are the following systems: ${ }^{20}$

\section{COUNTRIES DECLINING TO ENFORCE FOREIGN JUDGMENTS IN THE ABSENCE OF TREATY}

In certain countries no foreign judgment will be enforced in the absence of a treaty or international convention. To.this group belong: Finland, ${ }^{21}$ Haiti, ${ }^{22}$ Holland, ${ }^{23}$ Japan, ${ }^{24}$ Russia, ${ }^{25}$ Santo Domingo, ${ }^{28}$ Servia ${ }^{27}$ and probably also the Swiss cantons of Basel-Country, ${ }^{28}$ Neuchâtel ${ }^{28}$ and Unterwalden (Obwalden). ${ }^{30}$ In Norway ${ }^{31}$ and Sweden $^{32}$ the practice of the courts is not so clear, but it seems that in these countries also foreign judgments will not be enforced in the absence of treaty.

As no treaties relating to the subject have been entered into between

\footnotetext{
${ }^{20}$ Sper1, op. cit., 63-64.
}

${ }^{20}$ It will be observed that the actual state of the foreign law differs considerably from what was said concerning it in Hilton v. Guyot (1895) I59 U. S. II3, I6 Sup. Ct. 139.

${ }^{2}$ Francke, 8 Zeitschrift für deutschen Civilprozess, 46-47; 27 Zeitschrift fïr deutschen Civilprozess, I44.

$\Rightarrow$ Art. 470, Code Civ. P.

${ }^{23}$ Art. 43I, Code Civ. P.

${ }^{2}$ Art. 515 (5), Code Civ. P.

${ }^{25}$ Engelmann, Die Zwangsvollstreckung auswärtiger richterlicher Urteile in Russland, 23; I Klibanski, Handbuch des gesammten russischen Zivilrechts, 470.

${ }^{20}$ Gobian, L'exécution des jugements rendues par les tribunaux étrangers d’après la législation et la jurisprudence espagnole et hispano-americaine, Clunet (IgI3) roo.

${ }^{7}$ Georgevitch, 2 Leske $\mathcal{E}$ Löwenfeld, Rechtsverfolgung im internationalen Verkehr, 221.

Sec. 286 , Code Civ. P.

29 Art. 867 , Code Civ. P.

${ }^{s 0}$ Art. 246, Code Civ. P.

"Fliflet, Des effets des jugements étrangers en Norvègc, 34 Clunet, 932; Heiberg, Internationale Rechtsverfolgtıng, Verhandlung der internationalen juristischen Konferenz (I913). In Hause des Berliner Anwaltsvereins, II7; Synnestvedt, Le droit international privé de la Scandinavie, 304-305.

${ }^{2}$ Reuterskiöld, De la condition juridique des étrangers en Suède, Clunet (Ig06) 581; Synnestvedt, op. cit., 302; Uppström, 2 Leske \& Löwenfeld, op. cit., 483. 
the United States and any foreign government, American judgments cannot be enforced in the above countries or cantons. ${ }^{33}$ A new suit upon the original cause of action must therefore be brought.

In certain of the countries belonging to this group the foreign judgment may be received as evidence of the original obligation.

\section{COUNTRIES DECLINING TO ENFORCE FOREIGN JUDGMENTS IF THE PLAINTIFF OR DEFENDANT IS A SUBJECT OF SUCE COUNTRY}

In Turkey foreign judgments were enforceable before the war in suits between foreigners, but judgments to which a Turk was a party were not. A judgment rendered in a suit between subjects of the same country, other than Turkey, could be enforced directly by the consul of such country, except as against realty, with respect to which the co-operation of the Ottoman authorities was necessary. If the parties had different nationalties, and neither of them was a Turk, the judgment would be enforced by a consul of the country to which the defendant belonged. Such consul would apply the rules relating to the enforcement of foreign judgments governing in his country. ${ }^{34}$

3. COUNTRIES ENFORCING FOREIGN JUDGMENTS WITHOUT THE REQUIREMENT OF RECIPROCITY

(a) The Italian system. Of all the foreign countries enforcing foreign judgments as such, Italy has had the distinction for many years of having adopted the most liberal policy. According to this system the status of the foreign judgment is fixed once for all. The review of the judgment relates only to certain points which have no reference to the correctness of the decision. Before the foreign judgment is enforced a preliminary proceeding takes place (giudizio

\footnotetext{
Very few treaties exist with reference to the enforcement of foreign judgments. According to Haeger, $0 p$. cit., 24I, the following were in effect in I912: Between Aargau and Baden (I867); Baden and France (1846); Baden and Austria (I848, modified in I856); Austria-Hungary and Serbia (I88I); Belgium and France (1899); Denmark and Sweden (I861); Germany and France concerning Alsace-Lorraine (187I); Germany and Serbia (I892); France and Belgium (1899); France and Germany.concerning Alsace-Lorraine (187I); France and Italy (1860); France and Switzerland (I869); Italy and France (1860); Italy and Serbia (1880); Switzerland and France (1869); Switzerland and Spain ( 1898 ).

See also Lachau, Traités et projets du traités internationaux sur la compétence judiciaire, sur l'autorité et l'exécution des jugements. (1906) Revue de droit international privé, 66. Asser, De l'effet ou de l'exécution des jugements rendus à l'étranger en matière civile et commerciale. Revue de droit international et de législation comparée, I869, 82, 408, 473; I875, 385.

"Salem, 2 Leske \& Löwenfeld, op. cit., 408; De l'exécution des jugements étrangers en Turkie, Clunet (1888) 605, 613-6I5.
} 
di delibazione) whose object it is to ascertain whether the judgment was rendered by a court of competent jurisdiction, whether the defendant had due notice of the original proceeding, whether he appeared or was duly defaulted, and whether the enforcement of the foreign judgment would be contrary to the public policy of Italy. ${ }^{35}$ If the judgment satisfies these requirements, the justice or injustice of the plaintiff's claim will not be reviewed..$^{36}$

The above system is derived from the principle of the equality of all states, and rests upon the fundamental assumption that the judgments of other states are entitled to full trust and confidence. As in the case of domestic judgments, a foreign judgment so far as its merits are concerned, imports absolute verity-an irrebuttable presumption being created in favor of its fairness and inherent justice.

In adopting the above principle Italy expected that other countries would follow her example. Having been disappointed in her expectations Italy has now restricted somewhat her former liberal policy. ${ }^{37}$

According to this decree the merits of the foreign judgment may be inquired into in the following cases: (I) where the judgment is by default; (2) where the judgment has been obtained through the plaintiff's fraud; (3) where the judgment is based upon legal documents which have been recognized or pronounced to be forgeries since the judgment was rendered, or prior to that time, if the defendant was ignorant of such fact; (4) where a document of a conclusive character has been found subsequent to the trial which could not be produced at the trial owing to the plaintiff's conduct; (5) where the judgment was rendered under a mistake of fact resulting from the record or documents of the case. Such an error is deemed to exist if the decision was based upon a supposition of fact, the falsity of which has since been established beyond a doubt, or if the nonexistence of a fact was assumed, the existence of which has been positively established, provided that in either case the fact was not a point in issue and thus determined in the case.

The only countries that have followed the Italian policy are: Brazil, ${ }^{38}$ Portugal, ${ }^{39}$ San Marino ${ }^{40}$ and the Swiss cantons of Basel-

\footnotetext{
${ }^{85}$ Art. 94I, Code Civ. P. (before decree of July 30, 1919).

${ }^{86}$ Cass. Naples, Dec. 6, 1866, Annali, I, I, II9; Fiore, De l'exécution des actes et des jugements étrangers en Italie, Clunet (1879) 246.

I The matter is actually governed by the decree of July 30 , I9r9, the terms of which have been kindly communicated to me by my friend Professor G. C. Buzzati. See Diena, Sul progetto di riforma dell art. 941, Cod. proc. civ. circa l'esecuzione delle sentenze straniere,

${ }^{23}$ Law of Nov. 20, 1894, No. 221, tit. 2, ch. I, art. I2, sec. 4. Collę̧ão das leis (I894) I, rg.

"Art. 1088, Code Civ. P. With respect to Portuguese subjects the law of Portugal if applicable must be correctly applied.

* Giannini, La république de San Marino, Clunet (1899) 309.
} 
City $^{41}$ and Tessin. ${ }^{42}$ Costa-Rica ${ }^{43}$ also belongs to this group, the enforcement of foreign judgments being there restricted to those based on personal actions.

With respect to these countries there can be no doubt that American judgments for the payment of money can be enforced.

(b) The French system. Under the Ordinance of $1629^{44}$ the French courts would enforce foreign judgments obtained by Frenchmen without a review of the merits. No effect would be given, however, to foreign judgments against a Frenchman. As against them a new suit would have to be brought on the original cause of action. According to Maleville ${ }^{45}$ the law was not changed by the Code Napoléon, but this view is now generally abandoned. ${ }^{48}$ The system actually prevailing is one which reviews the merits of the case (révision an fond)..$^{47}$ It does not content itself with inquiring into the jurisdiction of the foreign court, the regularity of the service of the summons, appearance or default, and the public policy of the state in which the proceeding for the enforcement of the foreign judgment is brought; but examines the merits of the decision itself. The French doctrine rests upon an assumption diametrically opposed to that underlying the Italian system, and emphasizes the fact that while the different states of the civilized world are in theory equal and entitled to the same respect, their courts do not actually inspire the same degree of confidence in regard to their decisions. It takes notice of the fact that the judges of certain countries are less competent than those of others and are sometimes not free from bias against defendants belonging to a foreign country. Under these circumstances it is felt to be the duty of a state, before allowing the execution of foreign judgments within its territory, to ascertain whether the foreign judgment was fair and just. ${ }^{48}$

\footnotetext{
${ }^{12}$ Sec. 258, Code Civ. P. "Art. 1067, Code Civ. P.

Art. 528, Code Civ. P. "Art. I21.

${ }^{25}$ Maleville, Analyse raisomé de la discussion du code civil aux Conseil d'Etat, 269. The code provisions Art. 2123, Civil Code, and Art. 546, Code Civ. P. do not express themselves clearly on the point.

${ }^{4}$ See 2 Glasson, Précis théorique et pratique de procédure civile (2d ed.) 224; Pillet, Du droit de révision dans l'instance en exequatur des jugements étrangers. Clunet (r9I4) 755-756.

"The cases are too numerous to be mentioned. Of the late decisions the following may be mentioned: Cass. Dec. 9, rg03, Clunet (1904) 391; App. Paris, March 8, I901, Clunet (I90I) 560; rg02, 595; App. Lyon, Jan. 12, 1906, Clunet (1906) 790; Trib. civ. Seine, June 21, I906, Paris, Dec. 20, I907, Clunet (Ig08) 808; App. Paris, Feb. 20, I908, Revue de droit international privé, I908, 637; Trib. civ. Seine, Oct. 26, 1909, Paris, Jan. 27, 1911, Clunet (I912) II73; App. Toulouse, Feb. I2, I912, Clunet (I9I2) II75. There is a conflict regarding the question whether the review of the merits can be waived. In favor of such authority see Trib. civ. de Nantes, Nov. 25, 1895, Clunet (1896) 625. To the contrary, Toulouse, Jan. 29, I872, Sirey (1873) 2, 18.

Audinet, op. cit., 383 .
} 
Some of the French writers and decisions appear to favor the system of integral revision, according to which new issues may be raised, new proof offered and a different judgment rendered. ${ }^{42}$ Others hold that the right of revision on the part of French courts, called upon to enforce foreign judgments, is more restricted and support, therefore, the doctrine of limited revision. ${ }^{50}$ Some of these hold that the power possessed by the French court is that of a court of appeal. ${ }^{51}$ According to Pillet, ${ }^{52}$ foreign judgments will be enforced in France unless a gross error has been committed or their enforcement is incompatible with the most elementary notions of justice. ${ }^{53}$

The French courts purport to go on the theory that the exequatur proceeding involves no substitution of a French judgment for a foreign judgment. ${ }^{54}$ They hold, therefore, that no additional amount to that specified in the foreign judgment can be recovered, ${ }^{55}$ not even interest. ${ }^{86}$ The exequatur may be granted, however, for a smaller amount. $^{57}$ Contrary to the great weight of authority there are a

\footnotetext{
${ }^{9}$ App. Paris, June I5, 186r, Sirey, I86r, 2, 455; App. Douai, Dec. 22, 1863, Sirey (1865) 2, 60.

${ }^{50}$ Cass. Dec. 9, 1903, Clunet (1904) 39r.

2 Glasson, $o p$. cit., 246-247; I Vallette, Mélanges de droit, de jurisprudence et de législation, 346. Contra, Pillet, Clunet (1914) 765. According to Pillet the French courts exercise in fact only a slight control. Clunet (I9I4) 768-769.

${ }^{52}$ Clunet (I9I4) 77r.

The enforcement of a foreign judgment has been denied when in the opinion of the French judge the plaintiff had not proved his claim. App. Douai, Jan. 3,1845 , Sirey (1845) 2, 513; or when the foreign judge did not sufficiently appreciate the defense interposed by the defendant. App. Paris, April 22, I864, Sirey (1865) 2,60.

"App. Paris, June 15, rg12, Clunet (I913) 153; App. Toulouse, Feb. 12, 19I2, Clunet (Igr2) II75; Trib. civ. Seine, June 12, 1906, Clunet (Ig07) 745; Oct. 3, I9II, Clunet (I9I2) 533. Surville \& Arthuys maintain that the above is merely a question of words and that the French courts actually do substitute their own judgment for the foreign judgment-a practice which they deem contrary to Art. 2123 of the Code. Cours élémentaire de droit international privé (6th ed.) 6I6-6I7.

Glasson contends that injustice will be done unless the court is in a position to modify the foreign judgment. Op. cit., Vol. 2,246 .

The theory of the French courts logically applied should attach the same consequences to the foreign judgment as result therefrom in the foreign country. If several defendants are under the foreign law jointly and severally liable on the judgment the same liability should be imposed by the French courts. The decisions on the point are, however, in conflict. In favor of the logical principle Trib. civ. Seine, Dec. 10, I896, Clunet (I897) 543. Contra: App. Paris, June 7, I899, Clunet (1899) 828 .

${ }^{25}$ App. Bordeaux, June 29, I893, Clunet (I894) 323; Trib. civ. Seine, Nov. I6, 1883, Clunet (1883) 62I.

${ }^{56}$ App. Paris, Feb. 20, 1908, Clunet (1909) I07I.

${ }_{57}$ Trib. civ. Nantes, Nov. 25, 1895, Clunet (1896) 625; App. Paris, Jan. 28, 1837, Sirey (1837) 2, 173. Contra, App. Nancy, July 6, 1877, Sirey (1878) 2, 129.
} 
number of decisions which hold that the foreign judgment is conclusive with respect to the merits of the case. ${ }^{88}$

The system of revision is applied in Belgium, ${ }^{50}$ Luxemburg, ${ }^{80}$ and probably in the Swiss cantons of Freiburge1 and Geneva, ${ }^{62}$ in Egypt ${ }^{63}$ and $\mathrm{Monaco}^{84}$ if reciprocity does not exist, and in $\mathrm{Greece}^{85}$ if one of the parties is a Greek subject. In the above countries American judgments for the payment of money are not conclusive, with the qualifications just made, and will not be enforced without a re-examination of their merits.

(3) The English system. The English law by requiring a suit on the foreign judgment differs from the other foreign systems in the mode of enforcing foreign judgments for the payment of money. It differs from them also in that it regards foreign judgments as enforceable on principle and imposes upon the defendant the burden of establishing the defences recognized by law. As regards the conclusive effect of foreign judgments the English law stands between the French and Italian systems. Originally foreign judgments were regarded as being only prima facie evidence of the justice of plaintiff's claim, but since the case of Godard $v$. Gray ${ }^{88}$ they are ordinarily conclusive. In this respect the English law has abandoned the viewpoint of the French law and accepted that of Italy (before the decree of July 30, I9I9). It does not go so far, however, as does the former Italian law, for in exceptional cases it will try the merits of the case over again.

${ }^{58}$ App. Aix, Feb. 9, 1888, Clunet (1890) 274; Trib. de Laon, July 2I, I890, Clunet (1890) 909; App. Douai, March 17, 1900, Clunet (I90I) 785; Trib. civ. de Montbrisson,. Dec. 10, I904, Clunet (I905) 652; Trib. civ. de Boulogne sur Mer, Nov. 10, I905, April 27, 1906, Revue de droit international privé (1907) 751. According to Trib. civ. Seine, March 7, I913, Clunet (I913) 1243, the examination of the merits lies within the discretion of the court.

In favor of this system see also I Demolombe, Cour de Code Napoléon, No. 263; I Marcadé, Explications du Code Napoléon, No. 108; Surville \& Arthuys, op. cit., 6I9-620; Thevenet, op. cit., 50; 2 Vareilles-Sommières, Synthèse de droit international privé, I8; 6 Weiss, Traité de droit international privé, 7I. Contra, Valery, op. cit., 804.

Laine favors still another system. He would disallow a review of the merits but claims on behalf of the enforcing state an unlimited right of control. According to him the judge should ascertain whether the foreign judgment represented the serious and honest decision of a competent and conscientious judge and that it was reached without duress or fraud. Revue critique (I903) 507.

${ }^{80}$ Cass. Feb. 25, 1886, Clunet (1887) 217; Trib. civ. Anvers, Nov. 8, 1899, Clunet (1900) 818; App. Brussels, July 9, 1907, Clunet (1908) 569.

${ }^{\infty}$ Cass. June 19, 1908, Revue de droit international privé (1912) 504.

art. 653, Code Civ. P.; Meili, Das internationale Civilprozessrecht, 506-507.

Art. 479, Code Civ. P.; Meili, op. cit., 506-507.

${ }^{63}$ Clunet (1887) 533.

Art. 474, Code Civ. P.; Super. Ct., June 8, 1900. Clunet (rg02) 394; Nov. 4, I902, Clunet (I905) II47.

os Streit \& Diobouniotis; 2 Leske \& Löwenfeld, op. cit., 77.

${ }^{\circ}$ (I870) L. R. 6.Q. B. 139. 
The law appears to be established in England that foreign judgments may be impeached if procured by false and fraudulent representations and testimony of the plaintiff, even if the same question of fraud was presented to and decided by the foreign court. Such fraud may be shown although it cannot be done without a retrial of the case. ${ }^{67}$ The object of such retrial is not, however, to show that the foreign court came to a wrong conclusion, but that it was fraudulently misled into coming to a wrong conclusion. Courts of equity may enjoin the enforcement of judgments, domestic or foreign, if they have been procured through fraud, accident, mistake or surprise. ${ }^{68}$

The modern English doctrine has been followed in Canada with some local variations, and in other parts of the British Empire. ${ }^{89}$ In Quebec $^{70}$ any defence which was or might have been set up in the original action may be pleaded to an action brought upon the judgment rendered out of Canada. ${ }^{7 x}$

\section{COUNTRIES REQUIRING RECIPROCITY}

The great majority of foreign countries do not follow any of the systems so far discussed, but adopt the principle of reciprocity. The countries belonging to this group differ from those belonging to the Italian system in that they do not admit the principle of the conclusive effect of all foreign judgments. Nor do they support the system adopted by the French courts which review the merits of the foreign judgment in every case, with the object of ascertaining whether the decision was fair and just. The mere fact that the courts of a particular country present strong guarantees regarding the inherent justice of their decisions, is not sufficient to entitle their judgments to

${ }^{\circ}$ Abouloff v. Oppenheimer (1882) Io Q. B. Div. 295; Vadala v. Lawes (I890) 25 Q. B. Div. 310; Crozat v. Brogden (1894) 2 Q. B. 30; but see Cammell v. Servell, 27 L. J. Ex. 447; Bank of Australasia v. Nias (1857) 16 Q. B. 717; Robinson v. Fenner (I9I3) 3 K. B. 835. Whether a foreign judgment may be impeached if the law of the foreign country refuses to give such recognition to the law of other nations as is required by the principles of private international law is in doubt. See Simpson v. Fogo (1863) I H. \& M. 195. Dicey, Conflict of Laws (2d ed.) rule 94. According to Piggott the foreign judgment will be disregarded where the rule violated is held by the English court to be so universal in its application that it may be called a rule of international law. Foreign Judgments (2d ed.) 4I7-418. Cf. Westlake, Private International Law (5th ed.) 19I-192; Foote, Private International Jurisprudence (4th ed.) 540.

Pomeroy, Equitable Remedies, Secs. I56 et seq.

${ }^{20}$ The Indian Code of Civil Procedure (sec. 13) provides that foreign judgments shall not be conclusive when obtained by fraud.

${ }^{\text {ro }}$ Art. 2ro, Code Civ. P.

"It may be interesting to note that in his recent report to the Institute of International Law Professor Pillet has included fraud among the defenses that should be allowed to be set up in an action for the enforcement of foreign judgments. Annuaire de l'Institut de droit international (1913) 433. See also 2 Vareilles-Sommières, op. cit., 30. 
enforcement, nor does the absence of such guarantees in other countries preclude the enforcement of their judgments. The only test applied with respect to the enforceability of the judgments of a particular state is a political one-whether the courts of such state enforce the judgments of the state in which the question arises.

The following countries belong to the above group: Argentina, ${ }^{72}$ Austria, ${ }^{73}$ Bosnia-Herzegovina, ${ }^{74}$ Bulgaria, ${ }^{75}$ Chile, ${ }^{78}$ Colombia, ${ }^{77}$ Croatia and Slavonia, ${ }^{78} \mathrm{Cuba}^{, 7}$ Egypt, $^{80}$ Guatemala, ${ }^{81}$ Honduras, ${ }^{82}$ Hungary, ${ }^{83}$ Lichtenstein, ${ }^{84}$ Mexico, ${ }^{85}$ Monaco, ${ }^{86}$ Montenegro, ${ }^{87}$ Panama, ${ }^{88}$ Paraguay, ${ }^{89}$ Peru, ${ }^{90}$ Roumania, ${ }^{91}$ the Baltic Provinces of Russia, ${ }^{92}$ Spain, ${ }^{93}$ the Swiss cantons of Aargau, ${ }^{94}$ Appenzell (Outer Rhodes) ${ }^{96}$ Berne, ${ }^{96}$ Grisons, ${ }^{97}$ Lucerne, ${ }^{98}$ Saint Gall, ${ }^{90}$ Schaffhausen, ${ }^{100}$ Schwiz, ${ }^{101}$ Thurgau, ${ }^{102}$ Unterwalden (Nidwalden), ${ }^{103}$ Valais, ${ }^{104} \mathrm{Zug},{ }^{105}$ Zurich, ${ }^{106}$ Uruguay, ${ }^{107}$ and Venezuela. ${ }^{108}$

The great majority of the above countries whose law relating to the subject under discussion is statutory enumerate additional requirements to that of reciprocity, the particulars of which will be discussed hereafter and may be found in an appendix to this article. Some of the Swiss cantons, however,-Aargau, Appenzell (Outer Rhodes), Grisons, Lucerne, Saint Gall, Unterwalden (Nidwalden), and Zugcontent themselves with mentioning reciprocity as the sole condition for the enforcement of foreign judgments.

The requirement of reciprocity raises many intricate and difficult problems. Let us ascertain in the first place what is meant by reciprocity, how it is applied and how it is to be ascertained. A country having this requirement will not, of course, enforce the judgments of a foreign country which does not enforce its judgments. But what is its.significance if the foreign law does enforce its judgments? Will an

\footnotetext{
${ }^{72}$ Art. 872 , Code Civ. P.

${ }^{73}$ Law of May 27, 1896, art. 79.

${ }^{74}$ I Leske \& Löwenfeld, op. cit., 429.

${ }^{75}$ Art. 1209, Code Civ. P.

${ }^{70}$ Art. 240 , Code Civ. P.

"Art. 877, Code Civ. P.

${ }^{78}$ Sect. 550 (3), Code Civ. P.

${ }^{72}$ Art. 95I, Code Civ. P.

${ }^{80}$ Art. 468, Code Civ. \& Com. P.

${ }^{81}$ Art. 1564, Code Civ. P.

${ }^{82}$ Art. 627, Code Civ. P.

${ }^{83}$ Section $4 \mathrm{I} 4$ (6), Code Civ. $P$.

${ }^{84}$ Law of Dec. I6, I89I, art. I; Jettel, Handbuch des internationalen Privatund Strafrechts, 193-94.

${ }^{85}$ Art. 78I, Code Civ. P. $\quad{ }^{87}$ Art. 797, Code Civ. P.

${ }^{86}$ Art. 473, Code Civ. P. $\quad{ }^{83}$ Art. 582, Code Civ. P.

${ }^{89}$ Clunet (1886) 417, Clunet (1887) 556. ${ }^{\circ}$ Art. $1 \times 56$, Code Civ. P.

${ }^{21}$ Art. 374 (4), Code Civ. P. $\quad{ }^{100}$ Roguin, Io Clunet, 123.

${ }^{92}$ Engelmann, op. cit., 47. ${ }^{101}$ Sec. 307, Code Civ. P.

${ }^{\text {Qs }}$ Art. 952, Code Civ. P.

Sec. 378, Code Civ. P.

${ }^{95}$ Sec. II7, Code Civ. P.

${ }^{103}$ Meili, op. cit., 503.

${ }^{103}$ Sec. I73, Code Civ. $P$.

Meili, op. cit., 503.

${ }^{97}$ Art. 306, Code Civ. P.

Art. 325, Code Civ. P.

${ }^{\infty}$ Art. 339, Code Civ. P.

${ }^{104}$ Roguin, Io Clunet I26.

${ }^{105}$ Sec. 158, Code Civ. P.

${ }^{: 00}$ Art. 377, Code Civ. P.

${ }^{107}$ Art. 512, Code Civ. P.

${ }^{108}$ Art. 747, Code Civ. P.
} 
English judgment be enforced by means of a new suit upon the judgment and will the defences be those available in England in such action? Will the merits of a French judgment be examined within the limits established by the French courts and will an Italian judgment be examined with respect to the conditions laid down by the Italian Code of Civil Procedure? Or, will the foreign judgment be enforced only if the conditions required by the foreign country for the enforcement of foreign judgments are identical or substantially the same?

Modes of procedure are governed in all countries by the law of the forum, but there is a difference of view as to what matters fall within the purview of this rule. It would seem, however, that the method of enforcing a foreign judgment, whether by suit on the judgment or by some other procedure, should be controlled by the law of the state in which the enforcement is sought.

So far as the conclusiveness of foreign judgments is concerned, some countries give to them the same effect as is given by the courts of the foreign country to their judgments. ${ }^{100}$ If no effect is given, the judgment will of course not be enforced. ${ }^{110}$ If it is enforced only after re-examination of the merits, such a review will be made likewise. ${ }^{111}$ If foreign judgments are conclusive, but must satisfy more stringent requirements, the same conditions will be applied. ${ }^{112}$

In other countries the requirement of reciprocity has a different signification. The Austrian courts at one time regarded French judgments as conclusive notwithstanding the fact that the French courts would enforce Austrian judgments only after a review of their merits. The court would inquire only whether Austrian judgments were enforced in France, and paid no attention to the conditions under which such enforcement took place. ${ }^{113}$ This view has been abandoned, however, and to-day French judgments are enforced in Austria only after an examination of their merits. ${ }^{114}$ The law of Peru ${ }^{115}$ and Vene-

\footnotetext{
${ }^{100}$ Chile, art. 240, Code Civ. P.; Cuba, art. 95I, Code Civ. P.; Honduras, art. 627, Code Civ. P.; Panama, art. 582, Code Civ. P.; Uruguay, art. 512, Code Civ. $\mathrm{P}$.

${ }^{110}$ Chile, art. 24I, Code Civ. P.; Cuba, art. 952, Code Civ. P.; Honduras, art. 628, Code Civ. P.; Panama, art. 583, Code Civ. P.; Uruguay, art. 513, Code Civ. P.

${ }_{11}$ Egypt Mixed Court of Appeal, May 2, 190r, Clunet (I903) 905; Supreme Court of Austria, September 2I, I905, Revue de droit international privé (1909) 629. See also Sup. Ct. of Austria, Jan. 8, I89I, Clunet (I89I) 1003 , as to jurisdiction. If a foreign court inquired into the jurisdiction of the particular court, the Austrian courts would do so likewise. Canstein, I Leske \& Löwenfeld, op. cit., 429. According to Fürstl, reciprocity does not exist if the foreign law reviews the merits. 2 Die Oesterreichischen Civilprozessgesetze, I79.

${ }_{112}$ Argentina, art. 873, Code Civ. P.

${ }^{13} \mathrm{O}$ G H, Jan. 30, I884, Clunet (I888) r27; May 23, I893, Clunet (I894) 908.

"11 See note III.

${ }^{115}$ Art. I157, Code Civ. P.
} 
zuela ${ }^{116}$ expressly provide, on the other hand, that judgments of countries in which the merits of their judgments are reviewed, shall not be enforced. The same view will be taken no doubt without express legislation to that effect by other countries in which foreign judgments are deemed conclusive if reciprocity exists. ${ }^{117}$ In these countries no American judgment for the payment of money can be enforced if it was rendered in a state in which foreign judgments are deemed only prima facie evidence. Execution has been denied even to English judgments notwithstanding the fact that foreign judgments are regarded as conclusive on principle in England, because the English courts under exceptional circumstances, especially in connection with the defense of fraud, may inquire into the justice of the foreign decision. ${ }^{118}$ In countries taking this view it will be impossible, of course, to enforce American judgments which are rendered in states in which fraud relating to the original cause of action constitutes a defence to an action on a foreign judgment. ${ }^{118}$

A decision of the Imperial court of Germany of March 26, I909, 120 has given to the requirement of reciprocity a still wider meaning. The court was asked to permit the execution of certain California judgments which had been rendered by default against a German insurance company. The application was refused and the court based its decision in part on the ground that the courts of California would not enforce German judgments without inquiring whether the particular German court rendering the decision had jurisdiction, according to German law, over the person and subject-matter. Such a practice, which is con-

${ }^{110}$ Art. 747, Code Civ. P.

${ }^{11 \tau}$ Gestoso y Acosta, Nuevo Tratado de derecho procesal, civil, mercantil y penal internacional, 36r, and cases there cited. Compare, however, Gobian, Clunet (1912) 106I-62, who states that the same system will be applied.

${ }^{118}$ German Imperial Court, March 7, 1882, $7 \mathrm{R}$ G 406; cf., decision of May 19, 1882, $6 \mathrm{R} \mathrm{G}, 373$; Jan. 29, I883, $8 \mathrm{R} \mathrm{G}, 385$ (as to res judicata). These decisions were rendered under the former Code of Civil Procedure. Many writers feel that under subdivisions 3 and 4 of section 328 of the new code (see Appendix) which subjects the foreign judgment to a much wider review than was authorized by subdivision I of section $66 \mathrm{r}$ of the old code, reciprocity with respect to England should be recognized. See Inhülsen, x Leske \& Löwenfeld, op. cit., 689. A decision of O L G Hamburg, April 4, 1908, I7 Rechtsprechung der Oberlandesgerichte, 157 , admitted that under the provisions of the present code grave doubts had arisen concerning the correctness of the former decisions, but adhered to the old view as plaintiff had not adduced the requisite proof to establish reciprocity.

Spain has taken the same view with respect to English judgments. Medina y Marañon, Leyes civiles da España, ley de enjuicimiento civil, art. 951, note.

${ }^{119}$ According to the general American doctrine fraud constitutes a defence to an action of a foreign judgment only if the fraud related to the procurement of the judgment and not if it was or could have been raised in the original suit. Dunstan v. Higgins (1893) 138 N. Y. 70, 33 N. E. 729.

${ }^{120} 70 \mathrm{R} \mathrm{G} 434$. See also O G H, March 20, 1906, I6 Zeitschrift für internationales Privat- und Strafrecht, 406. 
trary to that of the German courts, the Imperial court regarded as an examination of the legality of the foreign judgment and equivalent to a review of the merits (révision an fond).

The exact meaning and scope of this doctrine it is difficult to determine, but in substance it seems to be that the enforcement of a foreign judgment will be denied if the courts of the state whose judgment it is sought to enforce, inquire, before giving effect to foreign judgment, whether it conformed to the internal law of such foreign country. ${ }^{121}$

Is it not singular that a German court should decline to enforce an American judgment because the courts of the United States go somewhat further than the German courts into the examination of the jurisdiction of foreign courts? If the requirement of reciprocity implies that the foreign law shall be the same in all its details it will not promote the enforcement of foreign judgments, but actually operate in the contrary direction. As long as the Imperial Court adheres to the above view, no American judgment can be enforced in Germany. If the above principles were applied to all cases alike not even an Italian judgment could have been enforced, notwithstanding the fact that the Italian system constituted the most liberal system on the continent of Europe. ${ }^{122}$

The position of the Imperial Court ${ }^{123}$ has created much adverse comment in Germany itself. ${ }^{124}$ Most of the writers are of the opinion that reciprocity should be deemed to exist within the meaning of the German law if the foreign court does not apply more stringent conditions with respect to the enforcement of foreign judgments than are prescribed by German law. ${ }^{125}$ Some of the writers argue with much force that

${ }^{121} 70 \mathrm{R} \mathrm{G}, 436$. A decision of the Kammergericht of Feb. 16, 1909, 19 Rechtsprechung der Oberlandesgerichte, I06, speaking of an American divorce decree said that a foreign judgment would be enforced only if the courts of the foreign state did not examine the legality of German judgments and that this would be presumed only with respect to states that had become parties to the Hague Convention relating to divorce, of June I2, I902.

According to the more common opinion there is no review of the merits (révision au fond) if the foreign judgment is respected and the review is limited to certain points. See Gaupp-Steir, op. cit., vol. I, 846; vol. 2, 415; Frankenstein, Internationale Rechtsverfolgung, 94; I Hellwig, Lehrbuch des deutschen Civilprozesses, $\mathrm{x} 36$.

${ }^{22}$ Wittmaack, Ist die Gegenseitigkeit im Simne des, 328, no. 5, Z. P. O. gegenüber Italien verbürgt? I5 Das Recht, 393.

${ }^{123} C f$., Decision of Imperial Court, April 7, I888, 44 Seuffert's Archiv, III; Jan. 26, 1892, 47 Seuffert's Archiv, 465.

${ }^{124}$ Frankenstein, op. cit., 94; I Gaupp-Stein, op. cit., 847, note 88; I Hellwig, Systcm, 832, note; Wittmaack, I5 Das Recht, 393.

Frankenstein says that nobody can tell to-day what reciprocity means in Germany and how the courts would decide a given case. Internationale Rechtsverfolgung, 9I-92, 96 .

${ }^{123}$ Francke, 7 Zeitschrift fiir deutschen Civilprozess, 56 f.; Frankenstein, Internationale Rechtsverfolgung, 95; Haeger, op. cit., 17; I Hellwig, Lehrbuch, 
inasmuch as subdivisions 3 and 4 of section $3^{28}$ of the German Code of Civil Procedure require an examination of the legality of foreign judgments to a much wider extent than was permissible under section 66I of the former code, ${ }^{126}$ the German courts should show greater liberality in the recognition of the existence of reciprocity with respect to foreign countries than they were justified in doing formerly. ${ }^{127}$

There are still other grounds which may preclude the enforcement of any American judgment for the payment of money in a country having the requirement of reciprocity. One is based on a difference in the mode of enforcing foreign judgments. Reciprocity might be deemed to be non-existing as regards England and the United States, because of the fact that judgments for the payment of money cannot be enforced in these countries by means of an exequatur proceeding, but only by a new suit on the foreign judgment. This view has actually been taken by the highest court of Austria in a decision of July I9, I $865^{128}$

The German Imperial Court in the case above referred to advanced another ground than the one above-mentioned to show that reciprocity did not exist with reference to California judgments. The learned court assumed that the existence of reciprocity at the time of the German proceedings for the enforcement of California judgments would be sufficient,- and before that time the California legislature had passed a law giving to foreign judgments the same effect as was possessed by California judgments. ${ }^{228}$ There was no doubt, therefore, that at the time of the proceedings in Germany, the merits of the case

136; I Petersen, Die Civilprozessordnung fïr das deutsche Reich (5th ed.) 674. See also decision of Kammergericht, April I6, I9I2, 25 Rechtsprechung der Oberlandesgerichte, 103 .

The conditions prescribed by the German law are found in sec. 328 of the Code of Civil Procedure, the provisions of which may be found in the appendix to this article.

203 Sec. 66r allowed such examination only for the purpose of ascertaining whether the execution of the foreign judgment would give effect to an act which cannot be enforced under German Law.

${ }^{127}$ I Hellwig, Lehrbuch, I36, note 27; I Hellwig, System, 832; Stein, 24 Zeitschrift für deutschen Civilprozess, 229.

${ }^{128}$ Glaser-Unger, Sammlung von civilrechtlichen Entscheidungen, no. 2228, vol. 5,144 .

${ }^{220}$ Sec. I915 of the Code of Civil Procedure of California provided that foreign judgments were presumptive evidence which could only be repelled by evidence of (I) want of jurisdiction, (2) want of notice to the party, (3) collusion, fraud or clear mistake of law or fact. This section was changed by the law of March II, I907, which was passed with the evident object of assuring the execution of judgments rendered in California against foreign, especially German, insurance companies in consequence of the earthquake. According to the new law foreign judgments "shall have the same effect as in the country where rendered, and also the same effect as final judgments rendered in this state." 
could not be reviewed by the courts of California in a suit upon a German judgment. The Imperial Court observed, however, that the true status of foreign judgments in the United States could not be detcrmined solely from the doctrine applied by American courts of law, and that it was necessary to take into consideration the powers with respect to judgments possessed by the American courts of equity. The conclusion reached was that the power of our courts of equity to enjoin the execution of foreign judgments procured by fraud, accident, mistake or surprise was farther reaching than the grounds of restitution recognized by section 580 of the German Code of Civil Procedure, and that a means was afforded thereby to challenge the merits of the judgment itself. ${ }^{130}$ Inasmuch as the German courts are not allowed to make such an examination, reciprocity was deemed not to exist. From this decision it would follow that the judgments of any state of this Union in which the merits of the case may be re-examined under any circumstances, either at law or in equity, will not be enforced in Germany.

The unfamiliarity of foreign countries with the operation of the systems of procedure prevailing in England and the United States may be sufficient in itself to create doubt and uncertainty in the minds of the foreign judges regarding the conclusive effect of foreign judgments in such countries, with the result that plaintiff will fail to establish the existence of reciprocity.

There is a final reason, which has not been advanced as yet by any foreign court,reciprocity may decline to give effect to American judgments. The long-established rule that a foreign judgment does not operate as a merger of the original cause of action, and that the plaintiff is free, therefore, to elect whether he will sue on the foreign judgment or bring a new suit on the original cause of action, is not yet abandoned in England ${ }^{131}$ or in the United States. ${ }^{132}$ This doctrine has no longer any rational basis in states regarding foreign judgments as conclusive, ${ }^{133}$ and serves only to furnish to the foreign countries requiring reciprocity another argument for holding that reciprocity does not exist.

130 "It is not impossible," said the learned court, "that the allegation of fraud may be the means of a more or less extensive re-examination of the merits of the case itself." $70 \mathrm{R} \mathrm{G}, 437$.

${ }^{131}$ Bank of Australasia v. Harding (1850) 9 C. B. 661 ; Smith v. Nichols (1839, N. C.) 5 Bing. 208.

${ }^{122}$ Wood v. Gamble (1853, Mass.) II Cush., 8; Eastern Township Bank v. Beebe \& Co. (1880) $53 \mathrm{Vt}$. I77; Black on Judgments (2d ed.) 847. Contra, Herrman on Estoppel and Res judicata, sec. 498. According to Alaska Commercial Co. $v$. Debrey (rga4) 2 Alaska, 303, a foreign judgment which is enforceable in this country under the doctrine of Hilion v. Guyot, supra, II3 will operate also as a merger of the cause of action.

${ }^{25 *}$ I Piggott, Foreign Judgments (2d ed.) 28, 45, 63-64. 
But for the doctrine of non-merger, and perhaps notwithstanding such doctrine, there would appear to be, upon a reasonable consideration of the matter, no sufficient grounds why judgments of those of our states in which foreign judgments are regarded as conclusive, should not be enforced in countries requiring reciprocity. This conclusion was reached also by Wittmaack, ${ }^{134}$ Councillor of the German Imperial Court, after a very thorough study of the American law.

So far it has been assumed that the condition of reciprocity existed only in the country which was asked to enforce a foreign judgment, but what if the foreign country has the same requirement? This question has great practical importance with reference to the judgments of our federal courts, which since Hilton $v$. Guyot ${ }^{135}$ recogniże foreign judgments as conclusive only if reciprocity exists in that regard. Suppose that the state of $X$ says to the state of $Y, I$ will enforce your judgments if you will enforce mine upon substantially the same conditions. A presents a judgment obtained in the state of $Y$ for enforcement in the state of $X$. If $A$ must prove that the judgments of the state of $X$ are actually enforced in the state of $Y$, it is quite likely that he may be unable to produce any actual precedents to that effect. ${ }^{136}$ Indeed if the state of $Y$ should insist upon the same proof when a judgment of the state of $\mathrm{X}$ were presented for execution in that state, and there is no reason why it should not, no precedent could be established in either state. In other words, the requirement of reciprocity would land us in a circulus inextricabilis, from which circle there is logically no escape. ${ }^{137}$ Reciprocity, logically applied, leads to the non-enforcement of the judgments of such states or countries as have the same requirement. ${ }^{138}$ This conclusion is not reached, however, in actual practice. The judgments of the state of $\mathrm{Y}$ will be enforced in the state of $X$, notwithstanding the requirement of reciprocity in both states, if the conditions attached to the enforcement of X's judgments in the state of $\mathrm{Y}$ are substantially similar to those prescribed by the law of $X$ for the enforcement of Y's judgments. In other words, a presumption is raised in the absence of proof to the contrary, that the judgments of the state of $\mathrm{X}$ will be enforced in the state of $Y$. The only code which has a specific provision on the subject is that of Croatia and Slavonia, ${ }^{139}$ which presumes the existence of reciprocity in the absence of special reasons for doubt. ${ }^{140}$ The

\footnotetext{
${ }^{134}$ Wittmaack, 22 Zeitschrift für internationales Privat- und Strafrecht, I. The same conclusions was reached by Knauth, I Rheinische Zeitschrift, 93; Schnitzler, 4 Deutsche Juristenzeitung, I54-155.

${ }^{135}$ Supra.

${ }^{135}$ See decision of the Supreme Court of Chile of May 10, 1907. Revue de droit international privé (I909) 970.

${ }^{157}$ So Gombeaux, Clunet (1908) 93.

${ }^{138}$ Flaischlen, 2 Leske \& Löwenfeld, op. cit., I63.

100 Sec. 530 (3).

${ }^{100}$ Restrepo-Hernandez advances the same solution with reference to the law of Colombia, op. cit., 572.
} 
suggestion has been made that such a presumption can be made only with respect to countries in which the requirement of reciprocity rests upon a statutory foundation, and not where it is established by court decisions. ${ }^{141}$ It would seem, however, that such a distinction cannot be made as regards the judgments of our federal courts. The requirement of reciprocity is made binding upon all lower federal courts by the decision of the Supreme Court of the United States in Hilton v. Guyot, and should be given the same weight as if it had been laid down by an Act of Congress.

According to the law of a considerable number of states, judgments relating to certain classes of cases will not be enforced. Will that.fact in itself prevent the enforcement of their judgments for the payment of money in countries requiring reciprocity? The answer appears to be in the negative, for reciprocity in part is deemed sufficient. ${ }^{142}$ In such a case the same distinction is drawn between the different classes of cases as is done by the state whose judgment it is sought to enforce. Hence if there is nothing in the way of the enforcement of foreign money judgments in such state, its judgments for the payment of money will be enforced. Nor is it necessary, it seems, that the foreign court should enforce the particular kind of judgment under consideration, the requirement of reciprocity being deemed satisfied if judgments of the same character are enforced. ${ }^{143}$

Must reciprocity exist at the time when the judgment was rendered or at the time when the proceedings for its enforcement are brought? The prevailing opinion appears to be that the time when the enforcement is sought should be controlling. ${ }^{144}$. Most authors regard the question as one of procedure, which is governed by the law existing at the time the particular proceeding is brought. ${ }^{145}$ Where reciprocity is established, however, by legislation specifically intended to meet a particular situation, such legislation may be disregarded. ${ }^{148}$

\footnotetext{
${ }^{14}$ Klein, 7 Zeitschrift für deutschen Civilprozess, 19.

12 I Hellwig, Lehrbuch, r37-138; I Hellwig, System, 832.

${ }^{10}$ I Gaupp-Stein, op. cit., 847; Haeger, op. cit., 18; Wittmaack, 22 Zeitschrift für internationales Privat- und Strafrecht, 13.

${ }^{14}$ Decision of Imperial Court, June 15, I898, 4I R G 424; March 26, I909, 70 R G, 434; O L G Celle, Dec. II, I907, I7 Rechtsprechung der Oberlandesgerichte, 158 .

${ }^{16 s}$ I Gaupp-Stein, op. cit., 839; Hedecker, 18 Zeitschrift für deutschen Civilprozess, 463 ; Kleinfeller, 19 Zeitschrift für internationales Privat- und Strafrecht, 565; Laband, I2 Deutsche Juristenzeitung, 871-872. Contra, Neumeyer, I2 Deutsche Juristenzeitung, r194; Kohler, Aenderung des Zwischenstaatsrechts im Bezug auf Vollstreckungstitel, I3 Deutsche Juristenzcitung, 276.

${ }^{116}$ I Gaupp-Stein, op. cit., 847, note 88; Haeger, op. cit., 2I ; I Hellwig, System, 832; Laband, Ein Nachspiel zur Katastrophe von San Francisco, i2 Deutsche Juristenzeitung, 871-872; Kirskalt, Die Vollstreckbarkeit Kaliformisher Urteile in Deutschland; I Leipziger Zeitschrift, 689, 702. . Most of the German writers would justify the decision of the Imperial court with reference to. the California
} 
The requirement of reciprocity is in certain countries not an absolute one. In Monaco, ${ }^{147}$ for example, foreign judgments will, in the absence of reciprocity, be enforced after a review of the merits. In the Spanish Code of Civil Procedure ${ }^{148}$ there is a provision to the effect that foreign judgments complying with certain prescribed conditions will be enforced if it is not possible to ascertain whether reciprocity exists or not. Chile, ${ }^{149} \mathrm{Cuba}^{150}$ Honduras, ${ }^{151}$ Panama $^{152}$ and Uruguay $^{\mathbf{1 5 3}}$ will enforce judgments of countries in which their own judgments are given effect, although reciprocity within the meaning of their codes does not exist, provided such judgments satisfy certain specified conditions.

In certain countries (Austria ${ }^{154}$ and Bulgaria) ${ }^{155}$ the existence of reciprocity in fact is not sufficient. In Austria it must have been declared by the government, and in Bulgaria by the minister of justice. Up to the present time no such declarations have been made in these countries with respect to the United States. In Hungary a declaration on the part of the minister of justice regarding the existence of reciprocity with the particular country is binding upon the courts. ${ }^{156}$

judgments on this ground. The apprehension of these writers that the California legislature would repeal the law of March II, 1907, as soon as its immediate object was attained, was without foundation, for the act is in force to-day.

(147 Superior Court, June 8, 1900, Clunet (I902) 394; Nov. 8, r902, Clunet (1905) 1147.

${ }^{148}$ Art. 954 .

${ }^{10}$ Art. 242, Code Civ. P.

${ }^{150}$ Art. 953, Code Civ. P.

${ }^{151}$ Art. 629, Code Civ. P.

${ }^{152}$ Art. 584, Code Civ. P.

${ }^{134}$ Art. 79, Law of May 27, 1896.

${ }^{153}$ Art. 514, Code Civ. P.

${ }^{165}$ Schischmanov, 2 Leske \& Löwenfeld, op. cit., 289.

${ }^{160}$ Sec. 414, subdiv. 6, par. 2, Code Civ. P.

(To be continued) 